J. Clin. Chem. Clin. Biochem.

Vol. 25,1987 , pp. $711-717$

(C) 1987 Walter de Gruyter \& Co. Berlin - New York

\title{
Determination of Thiocyanate in Plasma and Saliva without Deproteinisation and Its Validation as a Smoking Parameter
}

\author{
By P. Degiampietro, E. Peheim
}

Chemisches Zentrallabor der Universitätskliniken, Inselspital Bern

\author{
D. Drew, H. Graf
}

Abt. für Parodontologie, Zahnmedizinische Kliniken, Universität Bern and

\section{J. P. Colombo}

Chemisches Zentrallabor der Universitätskliniken, Inselspital Bern

(Received February 6/June 9, 1987)

Summary: A simple photometric procedure was developed for the determination of thiocyanate $\left(\mathrm{SCN}^{-}\right)$in plasma and saliva without deproteinisation or dialysis. Fe(III) ions form a red coloured complex with $\mathrm{SCN}^{-}$ with a maximum absorbance at $460 \mathrm{~nm}$. Mercury(II) nitrate is used to run a sample blank. A manual and an automated version (COBAS BIO) of the method is described. The method is linear up to $5000 \mu \mathrm{mol} / 1$ $\mathrm{SCN}^{-}$. The $\mathrm{CV}$ of the between-run precision is $2.8-8 \%$ for the manual and $2.6-6.6 \%$ for the automated method. The SCN ${ }^{-}$plasma concentration was $21-134 \mu \mathrm{mol} / \mathrm{l}$ in nonsmokers and $44-260 \mu \mathrm{mol} / 1$ in smokers. In mixed saliva, the concentration is much higher than in plasma: $1.57-5.5 \mathrm{mmol} / \mathrm{l}$ in smokers and $0.79-$ $3.9 \mathrm{mmol} / \mathrm{l}$ in nonsmokers. Plasma, but not oral fluid $\mathrm{SCN}^{-}$, is a valuable parameter for studying smoking habits in population surveys. However, its use is limited. In our experience only heavy smokers can be distinguished from nonsmokers.

\section{Introduction}

The plasma thiocyanate $\left(\mathrm{SCN}^{-}\right)$concentration is one of several indicators for testing exposure to tobacco smoke. It has been widely used in health screening programmes for the evaluation of smoking behaviour $(1-3) . \mathrm{SCN}^{-}$is usually determined photometrically as iron(III) $\mathrm{SCN}^{-}$in a protein-free solution. The proteins were either precipitated $(4,5)$ or dialysed on the autoanalyser $(6,7)$, but losses of thiocyanate due to coprecipitation in different deproteinisation procedures have been reported $(8,9)$.

Our objective was to develop a simple photometric procedure for the determination of thiocyanate in plasma and saliva without deproteinizing or dialysing the sample, and which could be easily automated.

\section{Materials and Methods}

\section{Apparatus}

Centrifugal analyser COBAS BIO (F. Hoffmann-La Roche, CH-4002 Basel, Switzerland), spectrophotometer UVIKON 810 (Kontron Instruments, $\mathrm{CH}-8010$ Zürich, Switzerland).

\section{Chemicals}

Acetoacetic acid lithium salt (SIGMA A-8509); ammonium thiocyanate $0.1 \mathrm{~mol} / 1$ (MERCK 9900); ascorbic acid (MERCK 127); Bilirubin-Control (DADE B5132); Brij 35 (MERCK 801962); chlorpromazine (Rhône Poulenc Pharma); ethylenediamine tetraacetic acid disodium salt, EDTA (MERCK 8418); iron(III) nitrate (MERCK 3883); nitric acid 1 mol/1 (Merck 9966); mercury(II) nitrate (MERCK 4434); sodium chloride (MERCK 6404); sodium pyruvate (MERCK 6619); sodium salicylate (MERCK 6601). 
Materials

Semi-micro glass cuvettes, HELLMA No. 104-05, $10 \mathrm{~mm}$ (KONTRON, CH-8048 Zürich Switzerland); dilutor "micro lab m" (Hamilton Bonaduz AG, CH-7402 Bonaduz, Switzerland); dispenser Eppendorf Multipipette 4780 and pipette $3130100 \mu \mathrm{l}$ (Eppendorf Gerätebau, D-2000 Hamburg 65, FRG).

\section{Reagents}

\section{Automated procedure}

Reagent: Brij $50.0 \mathrm{~g} / 1$, iron(III) nitrate $33.3 \mathrm{mmol} / \mathrm{l}$, nitric acid $225 \mathrm{mmol} / \mathrm{l}$.

Start Reagent: Mercury(II) nitrate $300 \mathrm{mmol} / \mathrm{l}$, nitric acid 750 $\mathrm{mmol} / \mathrm{l}$.

\section{Manual procedure}

Reagent A: Brij $60.0 \mathrm{~g} / \mathrm{l}$, iron(III) nitrate $40.0 \mathrm{mmol} / \mathrm{l}$, nitric acid $270 \mathrm{mmol} / \mathrm{l}$.

Reagent B: Mercury(II) nitrate $60 \mathrm{mmol} / 1$, nitric acid 150 $\mathrm{mmol} / \mathrm{l}$.

\section{Specimen}

Blood from 324 persons was placed in heparinized tubes and centrifuged at $1200 \mathrm{~g}$.

Whole mixed saliva was collected with the Salivette system (SARSTEDT, D-5223 Nümbrecht, FRG). After centrifugation at $400 \mathrm{~g}$ the clear saliva was used. Parotid saliva was collected using a canula and a $5 \mathrm{ml}$ syringe. Pure lemon juice on the tongue was used as a stimulant. Average collection time was $15 \mathrm{~min}$ for $1 \mathrm{ml}$ of saliva.

Procedures

The method was designed for an automated (COBAS BIO) and a manual (UVIKON 810) procedure. The absorbances were read at $460 \mathrm{~nm}$ (tab. 1). The calibration was performed with ammonium thiocyanate $250 \mu \mathrm{mol} / 1$ in sodium chloride $103 \mathrm{mmol} / \mathrm{l}$

\section{Statistics}

The Wilcoxon and the z-test were used for statistics.

\section{Results}

\section{Spectral characteristics}

Thiocyanate forms a red coloured complex with $\mathrm{Fe}(\mathrm{III})$. The absorbance is maximal at $460 \mathrm{~nm}$ (fig. 1). Chloride also forms a coloured complex with $\mathrm{Fe}(\mathrm{III})$.

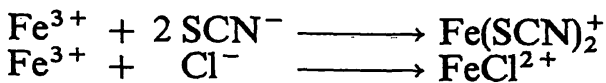

Interference from chloride is always encountered, since it is present in all body fluids. The interference of $\mathrm{FeCl}^{2+}$, however, is negligible at wavelengths above $460 \mathrm{~nm}$ (fig. 2). Therefore the absorbance of
Tab. 1. Procedures of thiocyanate determination.

Automated determination of thiocyanate

(COBAS BIO)

$\begin{array}{lll}1 & \text { Units } & \mu \mathrm{mol} / \mathrm{I} \\ 2 & \text { Calculation factor } & 2820 \\ 3 & \text { Standard 1 conc } & 0 \\ 4 & \text { Standard 2 conc } & 0 \\ 5 & \text { Standard 3 conc } & 0 \\ 6 & \text { Limit } & 5000 \\ 7 & \left.\text { Temperature ( }{ }^{\circ} \mathrm{C}\right) & 25.0 \\ 8 & \text { Type of analysis } & 6 \\ 9 & \text { Wavelength (nm) } & 460 \\ 0 & \text { Sample volume } & 25 \\ 1 & \text { Diluent volume ( } \mu l) & 50 \\ 2 & \text { Reagent volume ( } \mu \mathrm{l}) & 150 \\ 3 & \text { Incubation time (s) } & 600 \\ 4 & \text { Start reagent volume }(\mu \mathrm{l}) & 05 \\ 15 & \text { Time of first reading (s) } & 1.0 \\ 6 & \text { Time interval (s) } & 10 \\ 7 & \text { Number of readings } & 04 \\ 8 & \text { Blanking mode } & 1 \\ 9 & \text { Printout mode } & 1\end{array}$

\section{Manual determination of thiocyanate}

(UVIKON 810)

$100 \mu 1$ sample and

$300 \mu \mathrm{l}$ distilled water are pipetted into semi-micro glass cuvette and mixed.

$500 \mu \mathrm{l}$ Reagent $\mathrm{A}$ is added and mixed. After $10 \mathrm{~min}$, read absorbance $A_{1}$ at $460 \mathrm{~nm}$.

$100 \mu \mathrm{l}$ Reagent $\mathrm{B}$ is added and mixed. Read absorbance $A_{2}$ within 30 seconds. $c=2820\left(0.9 \mathrm{~A}_{1}-\mathrm{A}_{2}\right)$

the iron thiocyanate complex was measured at 460 $\mathrm{nm}$ (spectrophotometers) or at $492 \mathrm{~nm}$ (mercury line photometers).

$\mathrm{Hg}$ (II) forms colourless complexes with thiocyanate as well as with chloride. A sample blank can be performed by reading the absorbance before and after the addition of mercury(II) nitrate.

$$
\begin{aligned}
& \mathrm{Fe}(\mathrm{SCN})_{2}^{+}+\mathrm{Hg}^{2+} \longrightarrow \mathrm{Hg}\left(\mathrm{SCN}_{2}\right)_{2}+\underset{\mathrm{Fe}^{3+}}{\mathrm{FeCl}^{2+}} \\
& 2 \mathrm{FeCl}^{2+} \cdot+\mathrm{Hg}^{2+} \longrightarrow \mathrm{HgCl}_{2}+2 \mathrm{Fe}^{3++}
\end{aligned}
$$

\section{Composition of reagents}

In our laboratory Brij in hydrochloric acid 200 $\mathrm{mmol} / \mathrm{l}$ is used in the bilirubin method to prevent protein precipitation (10). Therefore Brij $30 \mathrm{~g} / 1$ was also introduced in the thiocyanate method. The reagent concentrations were optimized at $460 \mathrm{~nm}$ on a COBAS BIO at $25^{\circ} \mathrm{C}$. Nitric acid and iron(III) nitrate were varied between $25-400 \mathrm{mmol} / 1$ and 5$80 \mathrm{mmol} / 1$ respectively. Heparin plasma spiked with sodium thiocyanate $250 \mu \mathrm{mol} / 1$ was used. No proteins 


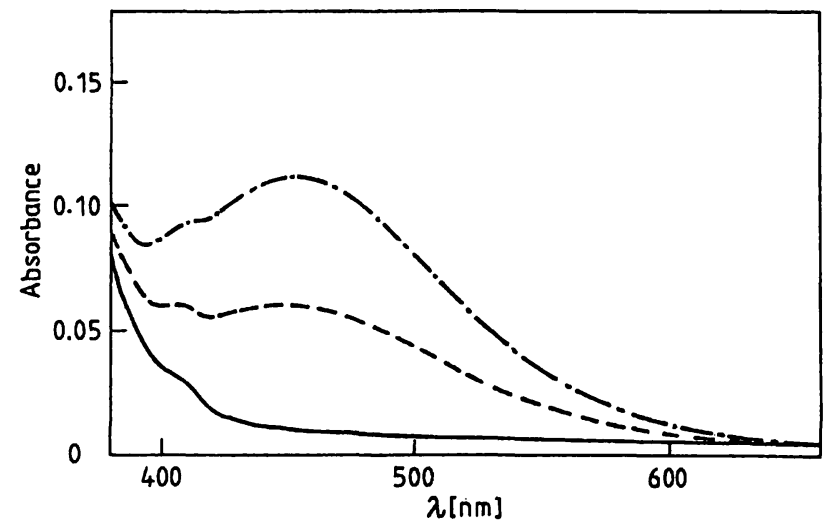

Fig. 1. Absorbance spectrum of iron(III) thiocyanate $500 \mu \mathrm{l}$ Reagent A, $300 \mu \mathrm{l}$ distilled water and $100 \mu \mathrm{l}$ ammonium thiocyanate $(\mu \mathrm{mol} / \mathrm{l})$ : $0(-), 125(---), 250(-\cdot-)$

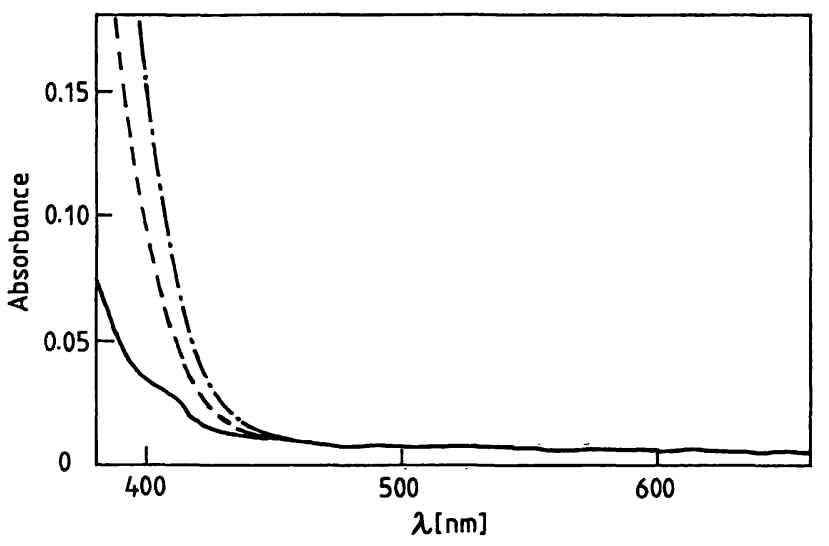

Fig. 2. Absorbance spectrum of iron(III) chloride $500 \mu \mathrm{l}$ Reagent A, $300 \mu \mathrm{l}$ distilled water and $100 \mu \mathrm{l}$ sodium chloride ( $\mathrm{mmol} / \mathrm{l})$ : 0 (—), $51.5(---), 103(-\cdot-)$

precipitate with nitric acid below $200 \mathrm{mmol} / \mathrm{l}$ and iron(III) nitrate below $40 \mathrm{mmol} / 1$ if the samples have been diluted with distilled water before adding the reagent (fig. 3).

The optimal mercury(II) nitrate concentration was determined with a maximal chloride concentration of $120 \mathrm{mmol} / \mathrm{l}$ in the sample. Due to its large excess chloride is bound first, although the chloride complex has a smaller complex formation constant than the thiocyanate complex (fig. 4).

The optimized final concentrations were: Brij $30 \mathrm{~g} / \mathrm{l}$, iron(III) nitrate $20 \mathrm{mmol} / \mathrm{l}$, mercury(II) nitrate 6.0 $\mathrm{mmol} / \mathrm{l}$, nitric acid $150 \mathrm{mmol} / \mathrm{l}$, sample volume fraction 0.1. The molar lineic absorbance of the iron(III) thiocyanate is $355 \mathrm{~m}^{2} / \mathrm{mol}$ at $460 \mathrm{~nm}$ and $291 \mathrm{~m}^{2} / \mathrm{mol}$ at $492 \mathrm{~nm}$.

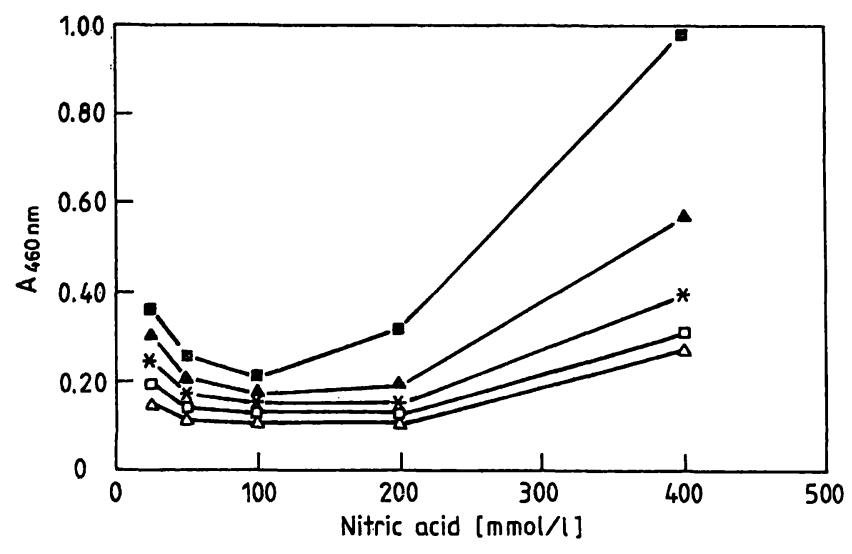

Fig. 3. Absorbance at different iron(III) nitrate and nitric acid concentrations

Brij $30 \mathrm{~g} / \mathrm{l}$, nitric acid $25-400 \mathrm{mmol} / \mathrm{l}$, sodium chloride $10 \mathrm{mmol} / \mathrm{l}$, ammonium thiocyanate $25 \mu \mathrm{mol} / \mathrm{l}$, iron(III) nitrate $(\mathrm{mmol} / \mathrm{l})$ :

$5(\Delta), 10(\square), 20(*), 40(\Delta), 80(\square)$

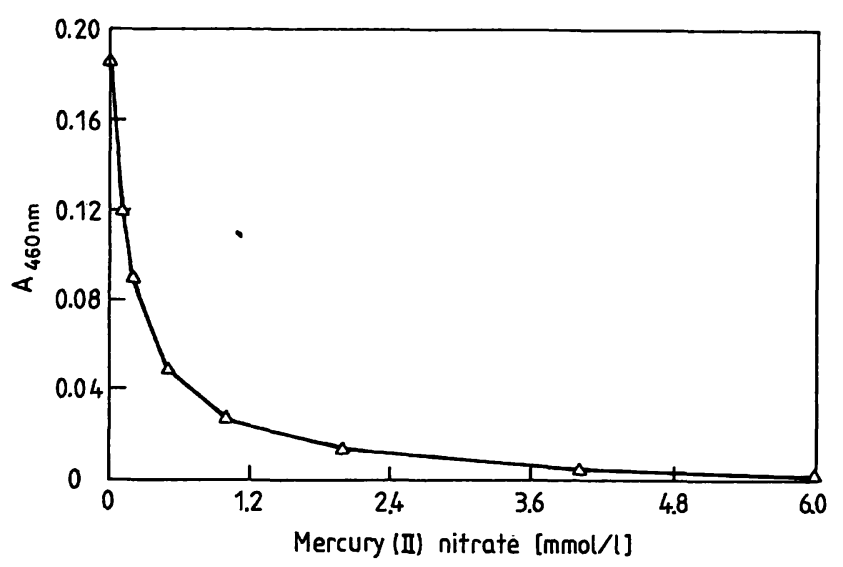

Fig. 4. Absorbance at different mercury(II) nitrate concentrations

Brij $30 \mathrm{~g} / \mathrm{l}$, iron(III) nitrate $20 \mathrm{mmol} / \mathrm{l}$, nitric acid 100 mmol/l, sodium chloride $12 \mathrm{mmol} / \mathrm{l}$, ammonium thiocyanate $25 \mu \mathrm{mol} / \mathrm{l}$, mercury(II) nitrate $0-6.0 \mathrm{mmol} / \mathrm{l}$

\section{Linearity}

The linearity was tested with ammonium thiocyanate $0-5000 \mu \mathrm{mol} / 1$ in sodium chloride $103 \mathrm{mmol} / \mathrm{l}$. A linear relationship between absorbance and thiocyanate concentration was found up to $5000 \mu \mathrm{mol} / \mathrm{l}(\mathrm{y}=$ $a+b x, \quad a=0.0085, \quad b=0.004, \quad r=0.999, \quad s_{y \cdot x}$ 0.0066).

\section{Interferences}

A pool of heparin plasma samples was used and spiked with acetoacetate, ascorbic acid, bilirubin, chlorpromazine, EDTA, haemoglobin, pyruvate and salicylate. The thiocyanate was determined at 460 and $492 \mathrm{~nm}$ on the COBAS BIO (tab. 2). Ascorbic acid, chlorpromazine, sodium pyruvate, sodium salicylate, EDTA and bilirubin do not interfere. Ace- 
Tab. 2. Interferences.

\begin{tabular}{|c|c|c|c|c|c|}
\hline \multirow[t]{2}{*}{ Substance } & & \multicolumn{2}{|l|}{$\lambda=460 \mathrm{~nm}$} & \multicolumn{2}{|l|}{$\lambda=492 \mathrm{~nm}$} \\
\hline & & $\begin{array}{l}\text { Found } \\
\text { thiocyanate } \\
(\mu \mathrm{mol} / \mathrm{l})\end{array}$ & $\begin{array}{l}\text { Interference } \\
(\%)\end{array}$ & $\begin{array}{l}\text { Found } \\
\text { thiocyanate } \\
(\mu \mathrm{mol} / \mathrm{l})\end{array}$ & $\begin{array}{l}\text { Interference } \\
(\%)\end{array}$ \\
\hline No addition (reference) & & 85 & - & 80 & - \\
\hline Acetoacetic acid (mmol/l) & $\begin{array}{l}2.0 \\
4.0 \\
6.0\end{array}$ & $\begin{array}{r}99 \\
112 \\
125\end{array}$ & $\begin{array}{l}+16.5 \\
+31.8 \\
+47.1\end{array}$ & $\begin{array}{l}100 \\
117 \\
131\end{array}$ & $\begin{array}{l}+25.0 \\
+46.3 \\
+63.8\end{array}$ \\
\hline Ascorbic acid (mmol/l) & $\begin{array}{l}2.0 \\
4.0 \\
6.0\end{array}$ & $\begin{array}{l}87 \\
87 \\
86\end{array}$ & $\begin{array}{l}+\quad 2.4 \\
+\quad 2.4 \\
+\quad 1.2\end{array}$ & $\begin{array}{l}83 \\
83 \\
82\end{array}$ & $\begin{array}{r}+3.8 \\
+\quad 3.8 \\
+\quad 2.5\end{array}$ \\
\hline Bilirubin $(\mu \mathrm{mol} / \mathrm{l})$ & $\begin{array}{l}17 \\
34 \\
51\end{array}$ & $\begin{array}{l}85 \\
84 \\
84\end{array}$ & $\begin{array}{r}0.0 \\
-\quad 1.2 \\
0.0\end{array}$ & $\begin{array}{l}78 \\
81 \\
81\end{array}$ & $\begin{array}{r}-2.5 \\
+\quad 1.3 \\
+\quad 1.3\end{array}$ \\
\hline Chlorpromazine (mg/l) & $\begin{array}{l}0.3 \\
0.6 \\
0.9\end{array}$ & $\begin{array}{l}85 \\
85 \\
85\end{array}$ & $\begin{array}{l}0.0 \\
0.0 \\
0.0\end{array}$ & $\begin{array}{l}77 \\
79 \\
80\end{array}$ & $\begin{array}{r}-3.7 \\
-\quad 1.2 \\
0.0\end{array}$ \\
\hline EDTA (mmol/l) & $\begin{array}{r}5.0 \\
10.0 \\
15.0\end{array}$ & $\begin{array}{l}85 \\
84 \\
83\end{array}$ & $\begin{array}{r}0.0 \\
-\quad 1.2 \\
-\quad 2.4\end{array}$ & $\begin{array}{l}81 \\
82 \\
80\end{array}$ & $\begin{array}{r}+\quad 1.3 \\
+\quad 2.5 \\
0.0\end{array}$ \\
\hline Haemoglobin $(\mathrm{g} / \mathrm{l})$ & $\begin{array}{l}0.9 \\
1.8 \\
2.7\end{array}$ & $\begin{array}{r}96 \\
108 \\
120\end{array}$ & $\begin{array}{l}+12.9 \\
+27.1 \\
+41.2\end{array}$ & $\begin{array}{l}84 \\
88 \\
90\end{array}$ & $\begin{array}{l}+\quad 5.0 \\
+10.0 \\
+12.5\end{array}$ \\
\hline Sodium pyruvate (mmol/l) & $\begin{array}{l}2.0 \\
4.0 \\
6.0\end{array}$ & $\begin{array}{l}86 \\
89 \\
90\end{array}$ & $\begin{array}{l}+\quad 1.2 \\
+\quad 3.5 \\
+\quad 5.9\end{array}$ & $\begin{array}{l}76 \\
79 \\
77\end{array}$ & $\begin{array}{r}1.2 \\
0.0 \\
+\quad 2.8\end{array}$ \\
\hline Sodium salicylate (mmol/l) & $\begin{array}{l}2.0 \\
4.0 \\
6.0\end{array}$ & $\begin{array}{l}82 \\
81 \\
82\end{array}$ & $\begin{array}{r}-3.5 \\
-\quad 4.7 \\
-\quad 3.5\end{array}$ & $\begin{array}{l}76 \\
79 \\
77\end{array}$ & $\begin{array}{r}-5.0 \\
-\quad 1.2 \\
-\quad 3.7\end{array}$ \\
\hline
\end{tabular}

toacetic acid $(1.0 \mathrm{mmol} / \mathrm{l})$ causes an overestimation of the thiocyanate concentration by $7 \mu \mathrm{mol} / 1$ ( 460 $\mathrm{nm})$ or $15 \mu \mathrm{mol} / \mathrm{l}(492 \mathrm{~nm})$, and haemoglobin $(1.0$ $\mathrm{g} / \mathrm{l})$ by $9 \mu \mathrm{mol} / 1(460 \mathrm{~nm})$ or $5 \mu \mathrm{mol} / \mathrm{l}(492 \mathrm{~nm})$.

\section{Precision}

The precision was examined at three concentration levels, using heparin plasma samples spiked with ammonium thiocyanate. For the between-run study, portions of frozen plasma were thawed each day, centrifuged and the thiocyanate determined in the supernatant.

The within-run precision $(\mathrm{n}=10)$ was checked in three separate runs (tabs. 3, 4). The standard deviation varies in the manual procedure from 2.3 to 6.9 $\mu \mathrm{mol} / 1$ ( $=0.0008$ to 0.0024 absorbance) and in the automated procedure from 0.57 to $1.70 \mu \mathrm{mol} / 1$ ( $=0.0002$ to 0.0006 absorbance). The coefficient of variation in the manual procedure appears high, especially at the low concentration range. The photometer has a resolution of \pm 0.001 absorbance, so . that the differences between the cuvette absorbances lead to a background deviation comparable to that of the standard deviation.

The between-run precision $(n=10)$ was examined over 10 days (tabs. 3,4 ). The coefficient of variation is $2.8-8.0 \%$ for the manual and $2.6-6.6 \%$ for the automated procedure. In the analysis of Monitrol II and Precinorm $\mathrm{U}$, we found thiocyanate concentra= tions below $20 \mu \mathrm{mol} / \mathrm{l}$. They cannot be used as quality control material. Pooled patient serum or thiocyanate solutions are preferable.

\section{Recovery}

Four different plasma samples $(900 \mu \mathrm{l})$ ) were each spiked with $100 \mu \mathrm{l}$ ammonium thiocyanate 1000 $\mu \mathrm{mol} / \mathrm{l}$. The concentration found was $2-3 \%$ lower than the added one (tab. 5).

\section{Plasma of nonsmokers and smokers}

Thiocyanate was determined in the plasma of 207 nonsmokers and 117 smokers on the COBAS BIO.

$$
\text { is }
$$

J. Clin. Chem. Clin. Biochem. / Vol. 25, 1987 / No. 10 
Tab. 3. Precision with automated procedure.

\begin{tabular}{|c|c|c|c|c|c|}
\hline & & \multicolumn{4}{|c|}{ Thiocyanate $(\mu \mathrm{mol} / \mathrm{l})$} \\
\hline & & \multicolumn{3}{|c|}{ within-run $(\mathrm{n}=10)$} & \multirow{2}{*}{$\begin{array}{l}\text { between } \\
\text { run } \\
(\mathrm{n}=10 \\
\text { days })\end{array}$} \\
\hline & & run 1 & run 2 & run 3 & \\
\hline Plasma A & $\begin{array}{l}\bar{x} \\
\text { SD } \\
\text { CV }(\%)\end{array}$ & $\begin{array}{c}62.1 \\
0.74 \\
1.19\end{array}$ & $\begin{array}{c}61.1 \\
0.88 \\
1.43\end{array}$ & $\begin{array}{c}63.0 \\
0.87 \\
1.37\end{array}$ & $\begin{array}{r}46.0 \\
3.06 \\
6.64\end{array}$ \\
\hline Plasma B & $\begin{array}{l}\bar{x} \\
\text { SD } \\
\text { CV }(\%)\end{array}$ & $\begin{array}{r}120.8 \\
0.63 \\
0.52\end{array}$ & $\begin{array}{r}119.8 \\
0.92 \\
0.77\end{array}$ & $\begin{array}{r}121.9 \\
0.57 \\
0.47\end{array}$ & $\begin{array}{r}101.0 \\
2.58 \\
2.56\end{array}$ \\
\hline Plasma C & $\begin{array}{l}\bar{x} \\
\text { SD } \\
C V(\%)\end{array}$ & $\begin{array}{r}243.1 \\
0.88 \\
0.36\end{array}$ & $\begin{array}{r}244.1 \\
0.57 \\
0.23\end{array}$ & $\begin{array}{r}247.7 \\
1.70 \\
0.69\end{array}$ & $\begin{array}{r}210.4 \\
5.42 \\
2.58\end{array}$ \\
\hline
\end{tabular}

Tab. 4. Precision with manual procedure.

\begin{tabular}{|c|c|c|c|c|c|}
\hline & & \multicolumn{4}{|c|}{ Thiocyanate $(\mu \mathrm{mol} / \mathrm{l})$} \\
\hline & & \multicolumn{3}{|c|}{ within-run $(n=10)$} & \multirow{2}{*}{$\begin{array}{l}\text { between- } \\
\text { run } \\
\text { (n }=10 \\
\text { days) }\end{array}$} \\
\hline & & run 1 & run 2 & run 3 & \\
\hline Plasma A & $\begin{array}{l}\overline{\mathbf{x}} \\
\mathrm{SD} \\
\mathrm{CV}(\%)\end{array}$ & $\begin{array}{r}53.0 \\
5.62 \\
10.60\end{array}$ & $\begin{array}{c}52.2 \\
2.30 \\
4.41\end{array}$ & $\begin{array}{c}53.2 \\
5.18 \\
9.74\end{array}$ & $\begin{array}{c}44.9 \\
3.60 \\
8.03\end{array}$ \\
\hline Plasma B & $\begin{array}{l}\overline{\mathrm{x}} \\
\mathrm{SD} \\
\mathrm{CV}(\%)\end{array}$ & $\begin{array}{r}114.1 \\
4.89 \\
4.28\end{array}$ & $\begin{array}{r}111.4 \\
4.25 \\
3.81\end{array}$ & $\begin{array}{r}112.9 \\
3.76 \\
3.33\end{array}$ & $\begin{array}{r}100.2 \\
4.05 \\
4.04\end{array}$ \\
\hline Plasma C & $\begin{array}{l}\overline{\mathrm{x}} \\
\mathrm{SD} \\
\mathrm{CV}(\%)\end{array}$ & $\begin{array}{r}227.7 \\
3.39 \\
1.49\end{array}$ & $\begin{array}{r}225.0 \\
6.86 \\
3.05\end{array}$ & $\begin{array}{r}238.8 \\
3.80 \\
1.59\end{array}$ & $\begin{array}{r}208.0 \\
5.89 \\
2.83\end{array}$ \\
\hline \multirow[t]{2}{*}{ Sample } & & \multicolumn{3}{|c|}{ Thiocyanate ( $\mu \mathrm{mol} / \mathrm{l})$} & Recovery \\
\hline & & Reference & \multicolumn{2}{|c|}{$+100 \mu \mathrm{mol} / \mathrm{l}$} & \\
\hline $\begin{array}{ll}\text { Plasma } 1 \\
\text { Plasma } 2 \\
\text { Plasma } 3 \\
\text { Plasma } 4\end{array}$ & & $\begin{array}{r}51 \\
53 \\
116 \\
199\end{array}$ & $\begin{array}{l}148 \\
151 \\
214 \\
296\end{array}$ & & $\begin{array}{l}97 \\
98 \\
98 \\
97\end{array}$ \\
\hline
\end{tabular}

Thiocyanate concentrations of $21-134 \mu \mathrm{mol} / 1$ (median 59) for nonsmokers and $44-260 \mu \mathrm{mol} / \mathrm{l}$ (median 127) for smokers were found (tab. 6). The results of the smokers overlapped widely those of the nonsmokers. In the nonsmokers thiocyanate concentrations were identical in females and males. Smoking females had a higher median value than males but their $95 \%$ range was very similar. The mean plasma thiocyanate concentration increased significantly according to the daily tobacco consumption (fig. 5). Heavy smokers ( $>20 \mathrm{~g} / \mathrm{d}$ ) had a very small overlap with nonsmokers.

\section{Saliva of nonsmokers and smokers}

Smokers showed significantly higher values of thiocyanate than nonsmokers in whole mixed saliva (1.575.5 , median $2.92 \mathrm{mmol} / 1$ versus $0.79-3.91$, median $1.67 \mathrm{mmol} / \mathrm{l} ; \mathrm{p}<0.05$ ). In stimulated parotid saliva we found concentrations from 1.27 to $2.40 \mathrm{mmol} / \mathrm{l}$ (tab. 7). They were higher than in whole mixed saliva of the same individual (tab. 7). All the saliva values were higher than those in plasma. Rinsing the oral cavity two times lowered the value from 1.58 to 1.08 mmol/l (median, $\mathrm{n}=10, \mathrm{p}<0.005$ ). This is probably due to a washout effect.

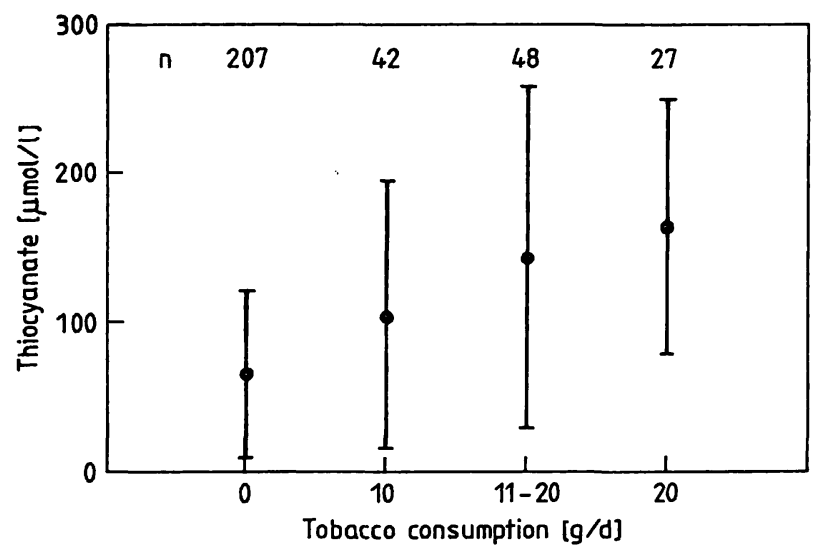

Fig. 5. Thiocyanate in plasma $(\bar{x} \pm 2 s)$ in relation to the tobacco consumption $(\mathrm{g} / \mathrm{d})$

Nonsmokers versus smokers $10,11-20,>20 \mathrm{~g} / \mathrm{d},(0$ to $>20, \mathrm{p}<0.001) ; 1 \mathrm{~g}$ of tabacco roughly compares to one cigarette (11).

Tạb. 6. Thiocyanate in plasma of nonsmokers and smokers.

\begin{tabular}{|c|c|c|c|c|c|c|c|c|}
\hline \multirow[t]{3}{*}{ Subject } & \multicolumn{8}{|c|}{ Thiocyanate $(\mu \mathrm{mol} / \mathrm{l})$} \\
\hline & \multicolumn{4}{|c|}{ Nonsmokers percentiles } & \multicolumn{4}{|c|}{ Smokers percentiles } \\
\hline & $\mathbf{n}$ & 2.5 & 50 & 97.5 & $\mathrm{n}$ & 2.5 & 50 & 97.5 \\
\hline $\begin{array}{l}\text { Females } \\
\text { Males } \\
\text { Total }\end{array}$ & $\begin{array}{r}49 \\
158 \\
207\end{array}$ & $\begin{array}{l}24 \\
21 \\
21\end{array}$ & $\begin{array}{l}60 \\
59 \\
59\end{array}$ & $\begin{array}{l}121 \\
134 \\
134\end{array}$ & $\begin{array}{r}34 \\
83 \\
117\end{array}$ & $\begin{array}{l}34 \\
45 \\
44\end{array}$ & $\begin{array}{l}141 \\
124 \\
127\end{array}$ & $\begin{array}{l}252 \\
264 \\
260\end{array}$ \\
\hline
\end{tabular}


Tab. 7. Thiocyanate in 10 whole saliva and parotid saliva samples of the same individuals.

\begin{tabular}{lll}
\hline Subject & \multicolumn{2}{l}{ Thiocyanate $(\mathrm{mmol} / \mathrm{l})$} \\
\cline { 2 - 3 } & whole saliva & parotid saliva \\
\hline 1 & 1.59 & 2.34 \\
2 & 1.28 & 1.51 \\
3 & 1.48 & 2.38 \\
4 & 1.87 & 2.40 \\
5 & 1.40 & 2.01 \\
6 & 0.72 & 1.27 \\
7 & 1.75 & 2.30 \\
8 & 1.73 & 1.85 \\
9 & 1.71 & 2.36 \\
10 & 1.57 & 2.03 \\
\hline Minimum & 0.72 & 1.27 \\
Median & 1.58 & 2.17 \\
Maximum & 1.87 & 2.40 \\
\hline
\end{tabular}

\section{Discussion}

The method allows the determination of $\mathrm{SCN}^{-}$ without protein precipitation. A sample blank is prepared by adding mercury nitrate. The performance of the method described is good. Interference by the substances tested is minimal. Acetoacetate and haemoglobin interfere, leading to falsely elevated concentrations, of $\mathrm{SCN}^{-}$. However, even the lowest concentration of acetoacetate used for the interference studies is rarely encountered in patients. Haemolysis of the sample must be avoided. The automated method is rapid and useful for large population surveys.

The plasma level of $\mathrm{SCN}^{-}$is influenced by the diet, drugs, elimination rate and mainly smoking habits.

Certain vegetables of the genus Brassica, e.g. cabbage, turnips, different types of kales and rape, contain appreciable amounts of $\mathrm{SCN}^{-}$(up to $300 \mathrm{mg}$ / $\mathrm{kg}$ fresh material) (12). 3-Indolylglucothiocyanates are split by thioglucosidase (EC 3.2.3.1) into glucose and isothiocyanates. Isothiocyanate is converted to $\mathrm{SCN}^{-}$by thiocynate isomerase (EC 5.99.1.1) (13). Normal amounts of $\mathrm{SCN}^{-}$-containing foods do, however, not significantly influence $\mathrm{SCN}^{-}$plasma levels (1).

Sodium nitroprusside (sodium nitrosylpentacyanoferrate(II)), often used as a hypotensive agent, contributes to $\mathrm{SCN}^{-}$plasma levels (14). It is first degraded to $\mathrm{HCN}$ and then to $\mathrm{SCN}$ by thiosulphate sulphurtransferase (rhodanase) (EC 2.8.1.1) in the liver, kidney and the gastrointestinal tract.
Another factor influencing the sensitivity of plasma $\mathrm{SCN}^{-}$is the elimination rate. Recently Junge determined the biological half life of $\mathrm{SCN}^{-}$to be 6 days (15). This is half the previously cited time of 10 to 14 days (1), based on the findings of Pettigrew \& Fell (16).

The main application of $\mathrm{SON}^{-}$determination in plasma is the evaluation of smoking exposure. The $\mathrm{SCN}^{-}$measured in the plasma of smokers originates from $\mathrm{HCN}$ inhaled from tobacco smoke. Our data, as well as those of others, demonstrate that plasma $\mathrm{SCN}^{-}$discriminates the groups of heavy smokers but its sensitivity is too low for detection of light smoking (1). This was observed in an intervention study for cardiovascular risk factors in Switzerland (11).

The $\mathrm{SCN}^{-}$concentrations in whole saliva were in the same range and higher in smokers than in nonsmokers, as reported by others $(1,17,18)$. In stimulated parotid saliva the concentrations found $(1.27-2.40$ $\mathrm{mmol} / \mathrm{l})$ are higher than those reported by Pruitt et al. of $0.76 \pm 0.55$ (SD) (19). The $\mathrm{SCN}^{-}$concentrations in parotid and whole saliva are about 30 times higher than in plasma. Thus SCN- must accumulate in the parotid gland and be secreted through a process which is still unexplained. This is also the case for hypocyanate $\left(\mathrm{OSCN}^{-}\right)$, a degradation product of $\mathrm{SCN}^{-}$(19), which functions as an antimicrobial agent (20). Extremely high flow rates (up to $3 \mathrm{ml} / \mathrm{min}$ ) could lower the $\mathrm{SCN}^{-}$concentration by dilution. However, it is improbable that it could account solely for these large concentration differences. The levels of $\mathrm{SCN}^{-}$ in saliva are also influenced by diet and smoking habits and show a larger scatter than the plasma values. In addition, the production of hypocyanate in the oral cavity by the antimicrobial peroxidase system requires $\mathrm{SCN}^{-}$, thereby contributing to the interindividual variations $(19,20)$. It must also be emphasized that rinsing the oral cavity changes $\mathrm{SCN}^{-}$concentrations. Whole salivary $\mathrm{SCN}^{-}$(oral fluid) is therefore certainly inferior to plasma with respect to its sensitivity for the evaluation of smoking habits $(1,3,17)$. In our opinion, it should not be used.

Plasma $\mathrm{SCN}^{-}$is an accepted parameter for the validation of smoking habits. However, based on our findings it seems to be more useful for the evaluation of the cessation of smoking in intervention studies (11), rather than for the detection of smokers in general population surveys. 


\section{References}

1. Bliss, R. E. \& O'Connell, K. A. (1984) Health Psychology $3,563-581$.

2. Gardner, M. J., McCarthy, T. L. \& Jusko, W. J. (1984) J. Toxicol. Environ. Health 14, 393-406.

3. Puddey, I. B., Vandongen, R., Beilin, L. J. \& Ukich, A. W. (1984) Aust. NZ J. Med. 14, 408-414.

4. Bowler, R. G. (1944) Biochem. J. 38, 385-388.

5. Augsten, M. \& Depersdorff, J. (1982) Z. Med. Labor.Diagn. 23, 226-228.

6. Butts, W. C., Kuehnemann, M. \& Widdowson, G. M. (1974) Clin. Chem. 20, 1344-1348.

7. Vesey, C. J. \& Kirk, C. J. C. (1985) Clin. Chem. 31, 270274.

8. Stoa, K. F. (1957) Studies on thiocyanate in serum. University of Bergen, ARBOK 1957, Medisinsk rekke Nr. 2, A.S. John Griegs, Baktrykkeri, Bergen, Norway.

9. Thürkow, B., Jess, G. \& Weuffen, W. (1982) Pharmazie 37, 264-269.

10. Colombo, J. P., Peheim, E., Kyburz, S. \& Hoffmann, J. P. (1974) Clin. Chim. Acta 51, 217-219.
11. Nater, B., Gutzwiller, F., Abelin, Th., Degiampietro, P., Junod, B. \& groupe d'étude des PNR 1A: Evolution de la consommation de tabac dans 2 villes d'intervention el 2 villes témoins suisses. (1985) Rev. Epidém. et Santć Publ. $33,80-89$.

12. Weuffen, W., Franzke, C. \& Thürkow, B. (1984) Nahrung $28,341-355$.

13. Wagner, H. (1982) Pharmazeutische Biologie, Drogen und ihre Inhaltsstoffe 2. Aufl., Gustav Fischer Verlag, Stuttgart, pp. 88-91.

14. Vesey, C. J. \& Cole, P. V. (1985) Br. J. Anaesthesiol. 57, $148-155$.

15. Junge, B. (1985) Brit. Med. J. 291, 22.

16. Pettigrew, A. R. \& Fell, G. S. (1972) Clin. Chem. 18, 9961000.

17. Biglan, A., Gallison, Ch., Ary, D. \& Thompson, R. (1985) Addictive Behaviors 10,137-144.

18. Lamberts, B. L., Pruitt, K. M., Pederson, E. D. \& Golding, M. P. (1984) Caries Res. 18, 488-494.

19. Pruitt, K. M., Mansson-Rahemtulla, M. \& Tenovuo, J. (1983) Arch. Oral Biol. 28, 517-525.

20. Tenovuo, J., Pruitt, K. M. \& Thomas, E. L. (1982) J. Dent. Res. 61, 982-985.

Prof. J. P. Colombo, M.D.

Dept. of Clinical Chemistry Inselspital, University of Bern CH-3010 Bern 
